\title{
ЕФЕКТИВНІСТЬ СКЛЕРОТЕРАПІЇ ТА ПРЕГРАВІДАРНОЇ ПІДГОТОВКИ У ЖІНОК ІЗ БЕЗПЛІДДЯМ НА ТЛІ ЕНДОМЕТРІОЗУ
}

\author{
Ефективність склеротерапії та прегравідарної \\ підготовки у жінок із безпліддям на тлі \\ ендометріозу
}

\section{С. В. Хміль, І. І. Кулик}

Тернопільський національний медичний університет імені І. Я. Горбачевського МОЗ України

Резюме. Тривають дебати щодо вибору оптимальної тактики лікування перед екстракорпоральним заплідненням (ЕКЗ) та найкращого протоколу стимуляції суперовуляції у жінок з ендометріозасоційованим безпліддям із метою досягнення вагітності.

Мета дослідження - проаналізувати параметри індукції суперовуляції у жінок із безпліддям на тлі ендометріозу та оцінити результативність запропонованих протоколів екстракорпорального запліднення.

Матеріали і методи. У дослідження увійшло 105 жінок віком від 21 до 40 років з ендометріозасоційованим безпліддям, яких поділили на 3 групи: з неоперованими ендометріоїдними кістами, яким проводили склеротерапію та прегравідарну терапію перед протоколом контрольованої оваріальної стимуляції (КОС); з неоперованими ендометріоїдними кістами, яким перед протоколом КОС проводили склеротерапію, без прегравідарної підготовки; у яких в анамнезі було проведено хірургічне лікування ендометріоїдних кіст та призначена прегравідарна терапія перед протоколом КОС. Препарат FT 500 plus для жінок першої групи призначали в дозуванні 1 саше - 1 раз на день з 2-го або 3-го дня циклу протягом 2-х менструальних циклів (цикл, у якому проводилась склеротерапія та наступний цикл). Вітамін D призначали у профрілактичних дозах - 2000 ОД.

Результати. Про ефективність контрольованої оваріальної стимуляції у жінок з ендометріозасоційованим безпліддям із включенням склеротерапії та вітамінного комплексу з інозитолом та вітаміну $D_{3}$ свідчить кількість фролікулів 13,50 (10,00; 15,00), кількість отриманих ооцитів 10,50 (8,50; 12,00), з яких 85,71\% становили зрілі ооцити стадії М II, вихід бластоцист 3,00 (2,00; 4,00). При аналізі кількості ембріонів високого класу встановлено, що найбільшу їх кількість отримували у пацієнток, яким проводили склеротерапію $з$ прегравідарною підготовкою комплексним вітамінним препаратом з інозитолом та вітаміном $D_{3}$.

Висновки. У жінок з ендометріозасоційованим безпліддям, яким проводили склеротерапію та прегравідар-
Efficacy of sclerotherapy and preconception preparation in women with infertility against endometriosis

\section{S. V. Khmil, I. I. Kulyk}

I. Horbachevsky Ternopil National Medical University e-mail: kulyk_iryna1@ukr.net

Summary. The debate over the choice of optimal treatment tactics before IVF and the best protocol for superovulation stimulation in women with endometriosisassociated infertility to achieve pregnancy are continuing.

The aim of the study - to analyze the parameters of superovulation induction in women with infertility on the background of endometriosis and to evaluate the effectiveness of the proposed in vitro fertilization protocols.

Materials and Methods. The study included 105 women aged 21 to 40 years with endometriosis-associated infertility. Patients with endometriosis-associated infertility were divided into 3 groups: with unoperated endometrioid cysts, who underwent sclerotherapy and preconception preparation before the COS protocol; with unoperated endometrioid cysts, which were sclerotherapy before the COS protocol, without preconception preparation; in whom a history of surgical treatment of endometrioid cysts was performed and preconception preparation was prescribed before the COS protocol. The drug FT 500 plus for women of group 1 was prescribed in a dosage of 1 sachet - once a day from the 2nd or 3rd day of the cycle for 2 menstrual cycles (the cycle in which sclerotherapy was performed and the next cycle). Vitamin $D$ was prescribed in prophylactic doses of $2000 \mathrm{IU}$.

Results. The effectiveness of controlled ovarian stimulation in women with endometriosis-associated infertility with the inclusion of sclerotherapy and vitamin complex with inositol and vitamin $D_{3}$ is evidenced by the number of follicles $13.50(10.00 ; 15.00)$, the number of oocytes 10.50 (8.50); 12.00) of which $85.71 \%$ were mature oocytes of stage $M I I$, blastocyst number 3.00 (2.00; 4.00). When analyzing the number of high-class embryos, it was found that the largest number of them was obtained in patients who underwent sclerotherapy with preconception preparation with a complex vitamin preparation with inositol and vitamin $D_{3}$.

Conclusions. In women with endometriosis-associated infertility who underwent sclerotherapy and preconception preparation with a vitamin complex with inositol and vitamin 
ну підготовку вітамінним комплексом з інозитолом та вітаміном $D_{3}$ перед контрольованою оваріальною стимуляцією, параметри індукції ооцитів були вірогідно кращі, що зумовило більшу частоту настання вагітностей.

Ключові слова: ендометріоз; безпліддя; склеротерапія; інозитол; вітамін $\mathrm{D}_{3}$; едективність.

\section{ВСТУП}

Безпліддя на тлі генітального ендометріозу характеризується низкою специфрічних особливостей, які необхідно врахувати при виборі методів лікування. У кожному конкретному випадку лікування має бути індивідуальним, повністю враховувати усі клінічні фрактори, а також вплив захворювання та ефрект лікування на якість життя жінки $[1,2]$. Лікування пацієнток із зовнішнім генітальним ендометріозом передбачає не тільки відновлення репродуктивної фрункції, але і профрілактику поширених фрорм ендометріозу, які вимагають виконання органозберігаючих, реконструктивно-пластичних операцій, поліпшення якості життя жінок, особливо репродуктивного віку [3].

На сьогодні оптимального методу лікування даної категорії жінок немає. Тактика лікування жінок з ендометріозасоційованим безпліддям залежить від багатьох фракторів, зокрема від: віку пацієнтки, локалізації та ступеня поширеності, клінічних проявів, наявності фрертильності й необхідності відновлення репродуктивної фрункції, від супутніх гінекологічних захворювань, характеру і ступеня порушень фрункції гіпоталамо-гіпофрізарно-яєчниково-маткової системи, стану інших органів та систем, що забезпечують гомеостаз, індивідуальну чутливість до гормональних препаратів [4, 5]

Для відновлення репродуктивної фрункції у жінок із генітальним ендометріозом застосовується стимуляція фролікулогенезу, метою якої є отримання великої кількості фролікулів, вилучення 3 них яйцеклітин, та їх використання у програмах допоміжних репродуктивних технологій. Екстракорпоральне запліднення (ЕКЗ) - це терапія першої лінії у жінок з ендометріозасоційованим безпліддям [6].

Тривають дебати щодо вибору оптимальної тактики лікування перед ЕКЗ та найкращого протоколу стимуляції суперовуляції у жінок з ендометріозасоційованим безпліддям із метою досягнення вагітності. Науковці пропонують різні схеми лікування: тривале лікування а-ГнРГ перед протоколом КОС та довгий протокол стимуляції; використання диназолу або естропрогестинів протягом 3-6 місяців перед програмою ЕКЗ та довгий чи короткий протокол стимуляції з монотерапією гонадотропінами; використання кломіфену або інгібіторів ароматаз та гонадотропінів у протоколі КОС; ЕКЗ в природному циклі [7]. Проте до цього часу немає єдиної думки щодо вибору оптималь-
$D_{3}$ before controlled ovarian stimulation, oocyte induction parameters were better, leading to a higher incidence of pregnancies.

Key words: endometriosis; infertility; sclerotherapy; inositol; vitamin $\mathrm{D}_{3}$. efficacy.

ного протоколу стимуляції під час контрольованої оваріальної стимуляції.

Метою дослідження було проаналізувати параметри індукції суперовуляції у жінок із безпліддям на тлі ендометріозу та оцінити результативність запропонованих протоколів екстракорпорального запліднення.

\section{МАТЕРІАЛИ I МЕТОДИ}

У дослідження увійшло 105 жінок віком від 21 до 40 років з ендометріозасоційованим безпліддям, яким проводили лікування у медичному центрі «Клініка профресора С. Хміля». У групу порівняння увійшло 30 жінок 3 трубно-перитонеальним фрактором безпліддя, діагностованим за допомогою лапароскопії або ехосальпінгографії. У групу проспективного аналізу не включали пацієнток із ендометріозом III-IV ступенів; синдром полікістозних яєчників; фріброміомою тіла матки (субмукозною, симптомною субсерозною чи інтрамуральною, діаметром більше 2 см). Зовнішній генітальний ендометріоз був верифрікований під час лапароскопії і підтверджений патогістологічним дослідженням (едометріоїдна кіста яєчника чи ендометріоїдні кісти яєчників).

Пацієнток з ендометріозасоційованим безпліддям було поділено на 3 групи. Першу групу склали 34 жінки репродуктивного віку з неоперованими ендометріоїдними кістами діаметром до 6,5 см, яким проводили склеро-терапію та прегравідарну терапію перед протоколом КОС; другу групу - 36 жінок репродуктивного віку з неоперованими ендометріоїдними кістами розміром до 6,5 см, яким перед протоколом КОС проводили склеротерапію, без прегравідарної підготовки; третю групу - 35 жінок, яким в анамнезі було проведено хірургічне лікування ендометріоїдних кіст та призначено прегравідарну терапію перед протоколом КОС. Наявність кіст підтверджували дані УЗД та бімануальне обстеження.

Препарат FT 500 plus для жінок першої групи призначали в дозуванні 1 саше - 1 раз на день 3 2-го або 3-го дня циклу протягом 2-х менструальних циклів (цикл, у якому проводилась склеротерапія та наступний цикл). Жінкам третьої групи даний препарат рекомендували приймати у такому ж дозуванні, та після проведених гормональних обстежень у відповідний день циклу протягом 2-х менструальних циклів. 
Вітамін D призначали у профілактичних дозах 2000 ОД жінкам, у яких не було діагностовано дефріциту даного вітаміну та в середньотерапевтичних дозах при гіповітамінозі протягом 2-х менструальних циклів.

Процедуру склеротерапії проводили в умовах стерильної операційної з/без загального знеболювання на 6-8 день менструального циклу шляхом трансвагінальної пункції кісти та аспірації її вмісту під контролем трансвагінального УЗД, введення в капсулу кісти (не порушуючи їі цілості) склерозуючого розчину. В якості склерозанту використовувався $95 \%$ розчин етанолу, що інсталювали в об'ємі 50-100 \% від розміру кісти під контролем УзД з подальшою його аспірацією.

У всіх пацієнток використовували «довгий» протокол стимуляції з а-ГнРГ. Препарат «ДекапептилДепо» в дозі 3,75 мг - триптореліну («Decapeptyl», Ferring, Німеччина) вводили внутрішньом'язово на 19-21 день попереднього менструального циклу. Після досягнення супресії гіпофріза (підтверджену даними ультразвукового) пацієнткам проводили стимуляцію суперовуляції. В якості індуктора стимуляції росту фролікулів використовували препарат пролонгованої дії коліфолітропін альфра «Елонва» та рекомбінантний ФСГ «Пурегон». Елонву вводили в перший день стимуляції, «Пурегон» на 8-й день стимуляції. Дозу р-ФСГ підбирали індивідуально з урахуванням гормональних показників, віку пацієнток та відповіді яєчників на стимуляцію. В якості тригера овуляції використовували хоріонічний гонадотропін («Хоріомон» або «Прегніл»), даний препарат призначали пацієнтам у випадку двох і більше фролікулів діаметром 18-19 мм. В день введення а-ГнРГ та протягом усієї стимуляції проводили ультразвуковий контроль із застосуванням трансвагінального датчика з подальшим зазначенням діаметра фолікулів та товщини ендометрія.

Забір ооцитів проводили через 36 год після введення тригера овуляції, запліднення яйцеклітин та культивування ембріонів із подальшою імовірною вітрифрікацією або трансфером у порожнину матки на 5-6 день (стадія бластоцисти) здійснювали в умовах ембріологічної лабораторії.

Оцінку аспірованих ооцитів проводили після денудації, перед процедурою ICSI. Оцінювали генетичну зрілість яйцеклітин (GV, MI, MII). Опис моророметричних параметрів ооцитів проводили за допомогою наступних параметрів: оцінки прозорої оболонки (zona pellucida), її зовнішній вигляд, структура та товщина, зміни у величині та фрормі самого ооцита, якість цитоплазми (наявність цитоплазматичних включень, вакуолізація, цитоплазматична зернистість), характеристика перивітелінового простору, стан полярного тіла.

Результати запліднення оцінювали через 1619 год після процедури ICSI - співвідношенням зигот із двома пронуклеусами до загальної кількості ймовірних зигот. Якість дроблення ембріонів описували наявністю фрагментації цитоплазми та кількості й симетрією бластомерів. Вихід бластоцист оцінювали на 5-6 день. Якісну характеристику ембріонів на стадії бластоцисти проводили за системою Gardner. Після перенесення ембріонів у порожнину матки, пацієнтки отримували підтриму-

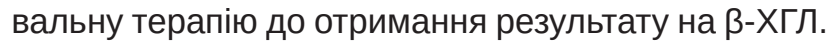
При позитивному результаті тесту на вагітність підтримку продовжували до 10-12 тижнів.

Статистичний аналіз результатів дослідження здійснювали за допомогою комп'ютерного забезпечення 3 використанням програм Microsoft Office Excell та Statistica 7.0. Вибір методу аналізу одержаних даних базувався на кількості груп, які включались в обстеження, правильності розподілу величин у них, а також рівностях дисперсій. При неправильному розподілі величин їх представляли у вигляді Mе (Q25; Q75) (медіани та Q25 і Q75 квартилів).

\section{РЕЗУЛЬТАТИ Й ОБГОВОРЕННЯ}

3 метою збереження оваріального резерву яєчників та видалення ендометріом перед протоколом ДРТ запропоновано відносно новий метод лікування - аспірацію кісти з подальшою склеротерапією [8, 9]. 3 метою корекції оксидативного стресу, який розвивається при ендометріозі, та веде до десректу гамет та/чи порушення ембріогенезу [1012], запропоновано використання інозитолу, який проявляє антиоксидантні властивості. Це відбувається шляхом хелатування фреруму за допомогою реакції Фентона. Точний механізм дії інозитолу як антиоксиданта не ясний; однак це може бути внаслідок фросфорилування до інозитол фроссратів [13]. Запропоновано, щоб вітамін D брав участь у патогенезі ендометріозу, оскільки він виявляє імуномодиорікуючі, протизапальні та антипроліферативні ознаки, хоча ця асоціація залишається підтвердженою [14].

У пацієнток групи порівняння 3 ендометріозасоційованим безпліддям тривалість стимуляції становила 10,5 $(10,0 ; 10,8)$ дня, тоді як у жінок першої групи тривалість стимуляції була 11,00 (10,00; 11,00) днів, при цьому мінімальна тривалість стимуляції була 10 днів, а максимальна - 12, у пацієнток другої групи тривалість стимуляції становила $11,00(11,00 ; 11,00)$, при цьому мінімальна тривалість стимуляції була 10, а максимальна - 13, у жінок третьої групи тривалість стимуляції становила 12,00 (11,00; 12,00) днів, при цьому мінімальна тривалість стимуляції була 11 , а максимальна - 13 днів. При цьому тривалість стимуляції різних дослідних груп вірогідно різнилася при проведенні аналізу рангових варіацій Крускала - Уолісса $(\mathrm{H}=28,73 ; \mathrm{p}<0,001)$, зокрема між першою і другою 
групами ( $\mathrm{H}=6,71, \mathrm{p}<0,01)$; між першою і третьою групами - H=27,16; p<0,001 та між другою і третьою групами - $\mathrm{H}=10,33 ; \mathrm{p}<0,001$.

Сумарна доза рекомбінантного ФСГ у пацієнток першої групи становила 900 (750; 1000), при цьому мінімальна доза складала $675 \mathrm{MO}$, а максимальна - 1250 МО, у пацієнток другої групи становила 1000 (900; 1100), при цьому мінімальна доза складала 750 МО, а максимальна - 1350 МО, у пацієнток третьої групи становила 1125 (1000; 1650), при цьому мінімальна доза складала $900 \mathrm{MO}$, а максимальна - 1650 МО. При цьому сумарна доза рекомбінантного ФСГ різних дослідних груп вірогідно різнилася при проведенні аналізу рангових варіацій Крускала - Уолісса $(\mathrm{H=30,82;} \mathrm{p<0,0001)} 3$ найнижчим значенням у першій групі.

у результаті контрольованої оваріальної стимуляції за довгим протоколом встановлено, що середнє число фролікулів пацієнток різних дослідних груп було статистично значимо нижче стосовно даних групи порівняння. Найнижча кількість фролікулів зафріксована у жінок, у яких в анамнезі було проведено хірургічне лікування ендометріоїдних кіст та призначено прегравідарну терапію перед протоколом КОС, при цьому вона була вірогідно менша результатів першої (на 68,75 \%) і другої (на 60,63 \%) груп. При аспірації отримували достовірно меншу кількість ооцитів у всіх дослідних групах стосовно групи порівняння, зокрема, у першій групі на 19,05 \%, відповідно у другій - на 31,58
\%, у третій - на 127,27 \%. При цьому найменшу кількість отриманих ооцитів зафріксовано в третій групі, яка була вдвічі меншою стосовно результатів у жінок після склеротерапії. Варто відмітити, що серед загальної кількості отриманих ооцитів 70,00 \% складали ооцити, отримані без промивки, і 30,00 $\%$ - отримані після промивки. Кількість зрілих ооцитів у стадії М II була вірогідно нижча у другій (на 33,33 \%) і третій (на 122,22 \%) групах відносно групи порівняння, при цьому виявлена вірогідна різниця також між даними першої і другої дослідних груп $(p=0,039)$. Варто відмітити, що відносна кількість зрілих ооцитів відносно загального числа ооцитів у першій групі становила 85,71 \%, відповідно в другій - 78,95 \% і у третій $-81,82$ \%. По 1 незрілому ооциту стадії М I виявлено в 14 жінок і по 2 - у 2 пацієнток першої групи, відповідно по 1 у 17 жінок і по 2 - в 1 пацієнтки другої групи і по 1 у 12 жінок третьої групи. Кількість дегенеративних орорм ооцитів (GV стадія) у першій групі становила $1(1 ; 1)$, в другій групі - $1(1 ; 2)$, і у третій - $1(1 ; 1)$.

Кількість запліднених яйцеклітин була найвищою у групі порівняння, хоча вірогідно не відрізнялася від результатів першої групи, тоді як найнижчі значення зафріксовані у пацієнток третьої групи. У жінок із безпліддям на тлі ендометріозу вихід бластоцист був вірогідно меншим у дослідних групах стосовно даних групи порівняння, при цьому в жінок із цистектомією в анамнезі та прегравідарною підготовкою зафріксовано найнижче число бластоцист (табл. 1).

\begin{tabular}{|c|c|c|c|c|}
\hline Показник & $\begin{array}{c}\text { Група порівняння } \\
(\mathrm{n}=30)\end{array}$ & $\begin{array}{c}\text { Перша група } \\
(\mathrm{n}=34)\end{array}$ & $\begin{array}{l}\text { Друга група } \\
\quad(n=36)\end{array}$ & Третя група $\quad(n=35)$ \\
\hline Кількість фролікулів & $15,0(16,5 ; 18,0)$ & $\begin{array}{c}13,50 * \\
(10,0 ; 15,00)\end{array}$ & $\begin{array}{c}12,85 *(10,00 \\
15,00)\end{array}$ & $\begin{array}{c}8,00 *(6,00 ; 10,50) \\
\mathrm{p}_{2-3}<0,05 \\
\mathrm{p}_{1-3}<0,05\end{array}$ \\
\hline $\begin{array}{l}\text { Кількість отриманих } \\
\text { ооцитів }\end{array}$ & $12,5(11,0 ; 15,0)$ & $\begin{array}{c}10,50 * \\
(8,50 ; 12,00)\end{array}$ & $\begin{array}{c}9,50 * \\
(6,75 ; 11,50)\end{array}$ & $\begin{array}{c}5,50^{\star} \\
(4,50 ; 8,00) \\
\mathrm{p}_{2-3}<0,05 \\
\mathrm{p}_{1-3}<0,05\end{array}$ \\
\hline $\begin{array}{l}\text { Кількість зрілих } \\
\text { ооцитів }\end{array}$ & $\begin{array}{c}10,0 \\
(10,5 ; 13,0)\end{array}$ & $9,00(7,00 ; 10,00)$ & $\begin{array}{c}7,50 *(5,00 ; 9,00) \\
\mathrm{p}_{1-2}<0,05\end{array}$ & $\begin{array}{c}4,50 \star \\
(3,50 ; 6,50) \\
\mathrm{p}_{2-3}<0,05 \\
\mathrm{p}_{1-3}<0,05\end{array}$ \\
\hline $\begin{array}{l}\text { Кількість усіх } \\
\text { запліднених клітин }\end{array}$ & $\begin{array}{c}9,0 \\
(7,3 ; 10,0)\end{array}$ & $\begin{array}{c}7,00 \\
(5,00 ; 9,00)\end{array}$ & $\begin{array}{c}5,80^{\star} \\
(4,50 ; 8,25)\end{array}$ & $\begin{array}{c}3,35 * 3,35 \\
(2,45 ; 5,15) \\
p_{2-3}<0,05 \\
p_{1-3}<0,05\end{array}$ \\
\hline Вихід бластоцист & $4,0(3,0 ; 5,0)$ & $\begin{array}{c}3,00 * \\
(2,00 ; 4,00)\end{array}$ & $\begin{array}{c}2,00 * \\
(2,00 ; 3,00) \\
p_{1-2}<0,05\end{array}$ & $\begin{array}{c}1,00 * \\
(1,00 ; 2,00) \\
\mathrm{p}_{2-3}<0,05 \\
\mathrm{p}_{1-3}<0,05 \\
\end{array}$ \\
\hline
\end{tabular}

Примітки: 1) * - статистично вірогідні результати стосовно контролю;

2) $p_{1-2}$ - статистично вірогідні результати між першою і другою дослідними групами;

3) $p_{2-3}$ - статистично вірогідні результати між другою і третьою дослідними групами;

4) $\mathrm{p}_{1-3}$ - статистично вірогідні результати між першою і третьою дослідними групами. 
При зіставленні виходу бластоцист у першій і другій групах встановлено вірогідно більшу їх кількість у жінок із склеротерапією та прегравідарною підготовкою комплексним вітамінним препаратом з інозитолом та вітаміном $D_{3}, p=0,012$.

Дані ретроспективних наукових досліджень вказують на те, що пацієнтки, у яких проводилася склеротерапія перед протоколом КОС, мали більшу кількість фролікулів та яйцеклітин, ніж пацієнтки, яким проводилась лапароскопічна кістектомія, проте різниці у показниках настання вагітності немає [15].

При зіставленні отриманих параметрів індукції суперовуляції у жінок із безпліддям на тлі ендометріозу третьої групи (цистектомія у пацієнток в анамнезі, яким прегравідарну підготовку здійснювали комплексним вітамінним препаратом 3 інозитолом та вітаміном $D_{3}$ ) 3 результатами у жінок із оперованими кістами в анамнезі з/без рецидивів встановлено відсутність вірогідних змін (рис. 1).

При аналізі кількості ембріонів високого класу встановлено, що найбільшу їх кількість отримували у пацієнток першої групи (склеротерапія з прегравідарною підготовкою комплексним вітамінним препаратом з інозитолом та вітаміном $D_{3}$ ), зокрема
3 ембріони отримували у 7 жінок, 2 - в 9 жінок і 1 - у 16 жінок. У пацієнток другої групи 3 ембріони отримували у 2 жінок, 2 - в 10 жінок і 1 - у 16 жінок, у пацієнток третьої групи, відповідно у 2; 5, і 14 жінок. Варто зазначити, що жодного ембріона високого класу не виявлено у 2 пацієнток першої групи, 7 - другої і 14 - третьої груп (рис. 2). Отже, проведення склеротерапії із прегравідарною підготовкою комплексним вітамінним препаратом з інозитолом та вітаміном $D_{3}$ не тільки впливає на кількість ембріонів, але й на якісні їх характеристики.

Якість яйцеклітин залежить від балансу оксидантів та антиоксидантів в організмі людини. У жінок із ендометріозасоційованим безпліддям часто спостерігають порушення антиоксидантного статусу, та, як наслідок, погану якість ооцитів, погану відповідь на стимуляцію в протоколах контрольованої оваріальної стимуляції, порушення імплантації [16]. Науковці відзначають, що жінки, які хворіють на ендометріоз, мають порушення вуглеводного та ліпідного обмінів, зокрема порушується експресія білка GLUT4 (глюкозо-4-транспортази), що сприяє накопиченню глюкози в гетеротопіях [17]; та спостерігають «несприятливий» ліпідний профріль (збільшення ліпідів низької щільності та зниження ліпопротеїнів високої щільності), внаслідок чого

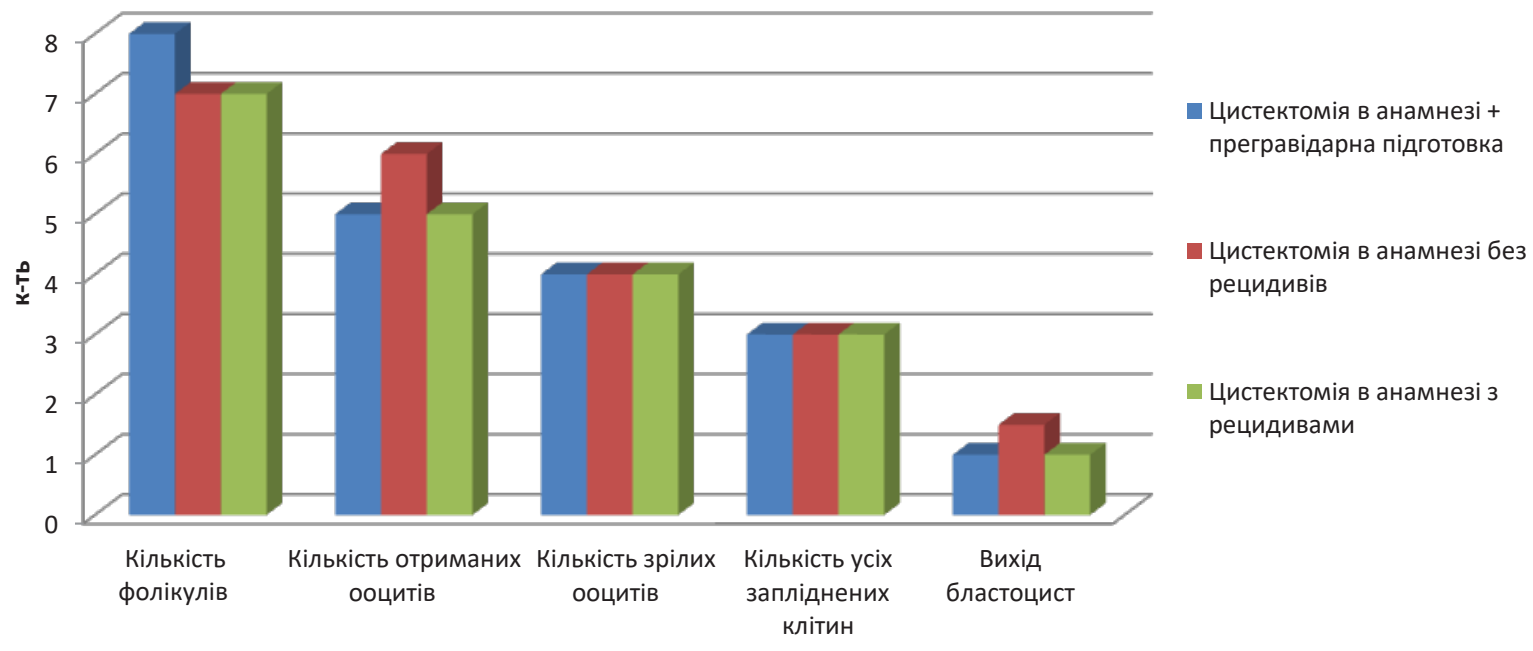

Рис. 1. Зіставлення параметрів індукції суперовуляції у жінок різних дослідних груп із безпліддям на тлі ендометріозу.

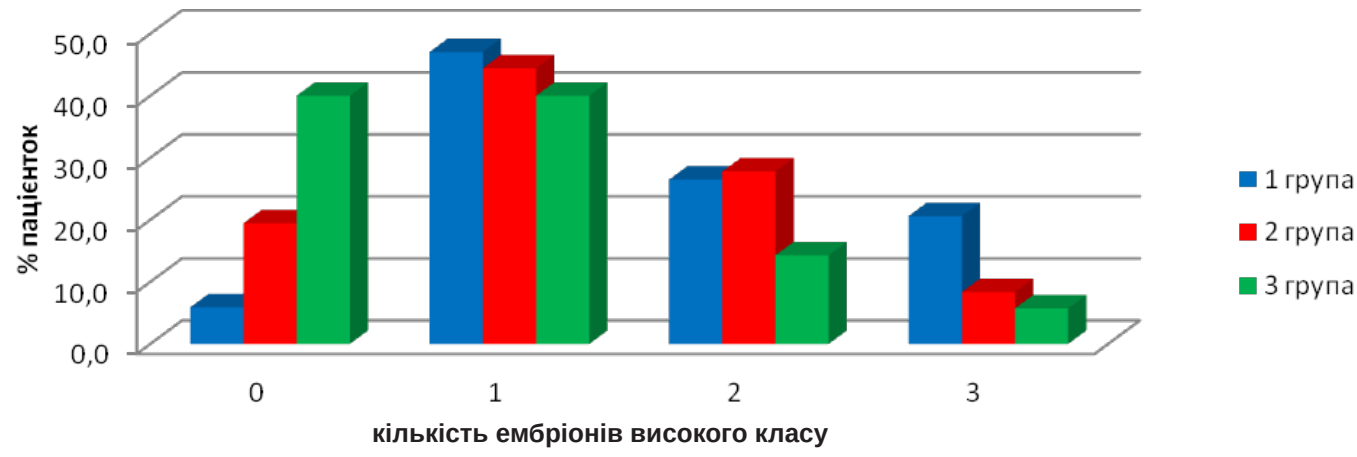

Рис. 2. Зіставлення кількості ембріонів високого класу в жінок різних дослідних груп із безпліддям на тлі ендометріозу. 
через систему пероксидного окиснення ліпідів потенціюється окиснювальний стрес $[18,19]$. Достатня концентрація інозитолу в фролікулярній рідині знижує рівень вільних радикалів та ушкодження мембранних білків та збільшує кількість ооцитів доброї якості. Його дефріцит призводить до атрезії фролікула [20].

Встановлено, що лише 1 пацієнтці першої групи було здійснено перенесення 1 ембріона, тоді як решта 33 жінкам переносили 2 ембріони. У другій групі 6 пацієнткам здійснено перенесення 1 ембріона, тоді як решта 30 жінкам переносили 2 ембріони. В третій групі 18 пацієнткам здійснено перенесення 1 ембріона, тоді як 15 жінкам переносили 2 ембріони. Варто також зазначити, що відсутність бластоцисти на день перенесення привело до виведення 3 протоколу 2 пацієнток третьої групи.

Про результативність КОС свідчило кількість ембріонів для кріоконсервації. Так, встановлено, що найбільшу кількість ембріонів для кріоконсервації отримували у пацієнток першої групи (склеротерапія 3 прегравідарною підготовкою комплексним вітамінним препаратом 3 інозитолом та вітаміном $D_{3}$ ), зокрема 2 ембріони у 7 жінок і 1 - в 16 жінок; у пацієнток другої групи 2 ембріони отримували в 4 жінок і 1 - у 12 жінок, в пацієнток третьої групи, відповідно у 1 і 4 жінок. Варто зазначити, що жодного ембріона для кріоконсервації не було в 11 пацієнток першої групи, 20 - другої і 30 - третьої груп (рис. 3). Отже, проведення склеротерапії з прегравідарною підготовкою комплексним вітамінним препаратом 3 інозитолом та вітаміном $D_{3}$ дає більшу кількість ембріонів для кріоконсервації для майбутніх перенесень.

Про результативність запропонованих протоколів ЕКЗ свідчить кількість вагітностей, що настали. Встановлено, що частота настання вагітностей у жінок першої групи складає 12 вагітностей (з них 1 біохімічно, 11 клінічно підтверджені), другої групи - 11 вагітностей (з них 2 біохімічно, 9 клінічно підтверджені) та третьої групи - 7 вагітностей (3 них 1 біохімічно, 6 клінічно підтверджені) (табл. 2).

При вивченні літератури встановлено, що вагітність після ЕКЗ у жінок із генітальним ендометріозом настає значно рідше, ніж у жінок 3 іншими фракторами жіночого безпліддя, що, у свою чергу, пов'язано зі зниженим відсотком запліднених клітин, імплантацією, малою кількістю отриманих ооцитів. Ймовірність настання вагітності залежить від ступень поширення процесу, зокрема у жінок із тяжкою фрормою ендометріозу вагітність настає рідше, ніж у жінок із легкою формою даного захворювання [21]. Дослідження науковців підтверджують низький коеоіцієнт частоти настання вагітності у жінок з ендометріозасоційованим безпліддям - 0,02-0,10 - порівняно зі здоровими жінками -0,15-0,20. У жінок 3 III-IV ступенями поширення ендометріозу даний показник ще нижчий: вірогідність настання вагітності щомісяця - 2-10\%, разом з тим, як у здорових пар - 15-25 \%. Це, насамперед, пов'язано з низькою здатністю до запліднення яйцеклітин, високим ризиком позаматкової вагітності, частим утворенням заоболонкових гематом під час вагітності, високою частотою спонтанних викиднів $[22,23]$.

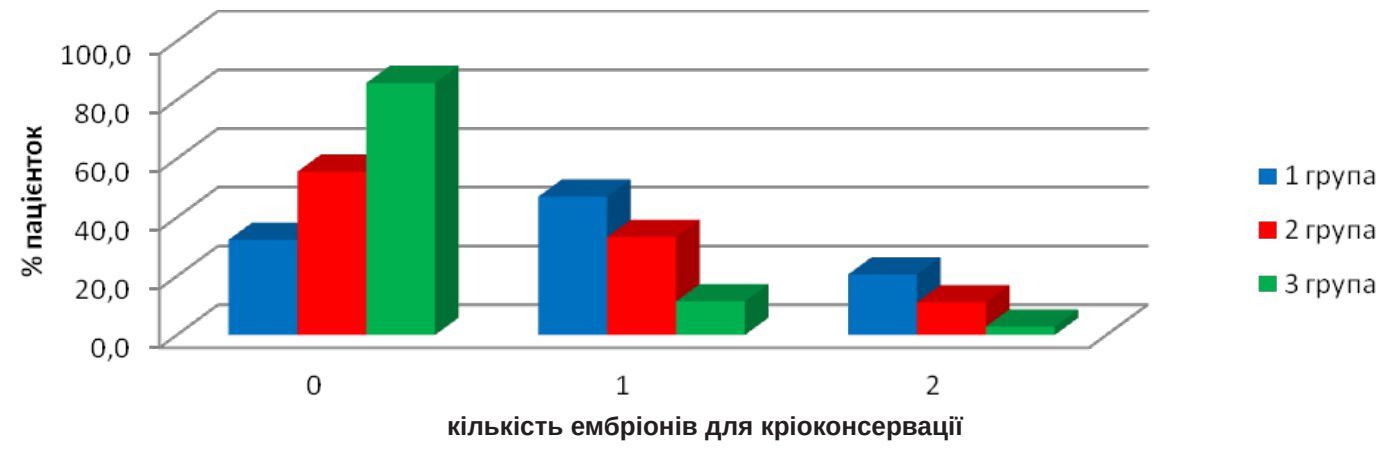

Рис. 3. Зіставлення кількості ембріонів для кріоконсервації у жінок різних дослідних груп із безпліддям на тлі ендометріозу.

Таблиця 2. Клінічні результати в дослідних групах пацієнток

\begin{tabular}{l|c|c|c}
\hline \multicolumn{1}{c|}{ Показник } & $\begin{array}{c}\text { Перша група } \\
(\mathrm{n}=34)\end{array}$ & $\begin{array}{c}\text { Друга група } \\
(\mathrm{n}=36)\end{array}$ & $\begin{array}{c}\text { Третя група } \\
(\mathrm{n}=35)\end{array}$ \\
\hline Частота настання вагітності, кількість & $\begin{array}{c}12 \\
(35,29 \%)\end{array}$ & $\begin{array}{c}11 \\
(30,56 \%)\end{array}$ & $\begin{array}{c}7 \\
(20,00 \%)\end{array}$ \\
\hline 3 них: & \multicolumn{3}{|c}{} \\
\hline Частота настання біохімічних вагітностей, \% & 8,33 & 18,18 & 14,29 \\
\hline Частота клінічних вагітностей, \% & 91,67 & 81,82 & 85,71 \\
\hline
\end{tabular}




\section{ВИСНОВКИ}

У жінок з ендометріозасоційованим безпліддям, яким проводили склеротерапію та прегравідарну підготовку вітамінним комплексом 3 іно-

\section{СПИСОК ЛІТЕРАТУРИ}

1. Giudice L. C. Clinical practice: Endometriosis / L. C. Giudice // N. Engl. J. Med. - 2010. - Vol. 362. P. 2389-2398.

2. Bulun S. E. Endometriosis / S. E. Bulun // N. Engl. J. Med. - 2009. - Vol. 360 (3). - P. 268-279.

3. Кучерина Н. С. Оптимізація лапароскопічного лікування хворих з апоплексією яєчника : автореф. дис. на здобуття наук. ступеня канд. мед. наук : спец. 14.01.01 «Акушерство та гінекологія» / Н. С. Кучерина. - Харків, 2009. - 21 c.

4. Practice Committee of the American Society for Reproductive Medicine (ASRM). Endometriosis and Infertility // Fertil. Steril. - 2006. - Vol. 14. - P. S156-160.

5. Taylor R. N. Endometriosis. In: Yen and Jafi' e's reproductive endocrinology: physiology and clinical management (6th cdn) / R. N. Taylor, D. I. Lebovic. - eds. J. F.Strauss, R. Barbicri. - New York: Elsevier, 2009. P. 577-595.

6. Endometriosis and infertility Surgery and ART: an integrated approach for successful management / M. E. Coccia, F. Rizzello, F. Cammilli [et al.] // Eur. J. Obstet. Gynecol. Reprod. Biol. - 2008. - Vol. 138 (1). - P. 54-59.

7. Endometriosis and assisted reproductive technology: A review article / A. Ajayi, V. Ajayi, I. Oyetunji // Medical \& Clinical Reviews. - 2017. - Vol. 3, No.1. - P. 4

8. ESHRE guideline: management of women with endometriosis / G. A. Dunselman, N. Vermeulen, C. Becker [et al.] // Hum. Reprod. - 2014. - Vol. 29. - P. 400-412.

9. Preliminary results: ethanol sclerotherapy after ultrasound guided fine needle aspiration without anesthesia in the management of simple ovarian cysts / V. M. Castellarnau, S. J. Ponce, C. R. Carreras [et al.] // J. Minim. Invasive Gynecol. - 2015. - Vol. 22. P. $475-482$.

10. Oxidative stress and its role in female infertility and assisted reproduction: clinical implications / S. Gupta, N. Malhotra, D. Sharma [et al.] // Int. J. Fertil. Steril. - 2009. - Vol. 2, No. 4. - P. 147-164.

11. Oxidative stress impairs oocyte quality and melatonin protects oocytes from free radical damage and improves fertilization rate / H. Tamura, A. Takasaki, I. Miwa [et al.] // J. Pineal Res. - 2007. - Vol. 44, No. 3. - P. 280287.

\section{REFERENCES}

1. Giudice LC. Clinical Practice: Endometriosis. N Engl J Med. 2010;362: 2389-98.

2. Bulun SE. Endometriosis. N Engl J Med. 2009;360(3): 268-79.

3. Kucheryna NS. Optimization of laparoscopic treatment of patients with ovarian apoplexy. Candidate's Extended abstract. Kharkiv; 2009. UKrainian.

4. Practice Committee of the American Society for зитолом та вітаміном $D_{3}$ перед контрольованою оваріальною стимуляцією, параметри індукції ооцитів були вірогідно кращі, що зумовило більшу частоту настання вагітностей.

12. Impact of oxidative stress on gametes and embryos in an ART laboratory / A. Agarwal, S. Gupta, H. Abdel-Razek [et al.] // Clin. Embryol. - 2006. - Vol. 9, No. 3. - P. 5-22.

13. Inositol \& its Phosphates: Basic Science to Practical Applications / A.K.M. Shamsuddin, Guang-Yu Yang // Bentham Science Publishers, 2015. - Access mode : https://doi.org/10.2174/97816810800791150101.

14. 25-hydroxyvitamin D serum levels and endometriosis: Results of a case-control study / L. Buggio, E. Somigliana, M. N. Pizzi [et al.] // Reprod Sci. - 2018.

15. The impact of endometrioma on IVF/ICSI outcomes: a systematic review and meta-analysis / M. Hamdan, G. Dunselman, T. C. Li, Y. Cheong // Hum. Reprod. Update. - 2015. - Vol. 21. - P. 809-825.

16. Effect of apoptosis and reactive oxygen species production in human granulosa cells on oocyte fertilization and blastocyst development / N. Jancar, A. N. Kopitar, A. Ihan [et al.] // J. Assist. Reprod. Genet. - 2007. - Vol. 24 (2-3). - P. 91-97.

17. Glucose transporter expression in eutopic endometrial tissue and ectopic endometriotic lesions / B. McKinnon, D. Bertschi, C. Wotzkow [et al.] // J. Mol. Endocrinol. - 2014. - Vol. 52 (2). - P. 169-179.

18. Unfavorablelipid profilein women withendometriosis/ A. S. Melo, J. C. Rosa-e-Silva, A. C. Rosa-e-Silva [et al.] // Fertil. Steril. - 2010. - Vol. 93 (7). - P. 2433-2436.

19. Low-density lipoproteins oxidation and endometriosis / G. Polak, B. Barczyński, W. Kwaśniewski [et al.] // Mediators Inflamm. - 2013. - Vol. 2013. - P. 624540.

20. Inositol and in vitro fertilization with embryo transfer / G. Simi, A. R. Genazzani, M. E. R. Obino [et al.] // International Journal of Endocrinology. - Vol. 2017. - 5 p.

21. GnRH agonist administration prior to embryo transfer in freeze-all cycles of patients with endometriosis or aberrant endometrial integrin expression / E. S. Surrey, M. Katz-Jaffe, L. V. Kondapalli, [et al.] // Reprod. Biomed. Online. - 2017. - Vol. 35. - P. 145-151.

22. The Practice Committee of the American Society for Reproductive Medicine. Endometriosis and Infertility: A committee opinion // Fertil. Steril. - 2012. - Vol. 98, No. 1034. - P. 299-315.

23. Halis G. Endometriosis and inflammation in infertility / G. Halis, A. Arici, N. Y. Ann // Acad Sci. - 2004. Vol. 1034. - P. 300-315.

Reproductive Medicine (ASRM). Endometriosis and Infertility. Fertil Steril. 2006;14:S156-60.

5. Taylor RN, Lebovic DI. Endometriosis. In: Yen and Jafi' e's reproductive endocrinology: physiology and clinical management (6th cdn). Strauss JF, Barbicri R. Eds. New York: Elsevier, 2009.

6. Coccia ME, Rizzello F, Cammilli F, Bracco GL, Scarselli G. Endometriosis and infertility Surgery and ART: 
an integrated approach for successful management. Eur J Obstet Gynecol Reprod Biol. 2008;138(1): 54-9. Epub 2008 Feb 20.

7. Abayomi Ajayi, Victor Ajayi, Ifeoluwa Oyetunji, Oluwafunmilola Biobaku, Happiness Aikhuele, Adedamilola Atiba and Bamgboye M Afolabi. Endometriosis and assisted reproductive technology: A review article. Medical \& Clinical Reviews 2017;3(1): 4.

8. Dunselman GA, Vermeulen N, Becker C, CalhazJorge C, d'Hooghe $\mathrm{T}$, de Bie B, et al. ESHRE guideline: management of women with endometriosis. Hum Reprod. 2014;29: 400-12.

9. Castellarnau Visus M, Ponce Sebastia J, Carreras Collado R, Cayuela Font E, Garcia Tejedor A. Preliminary results: ethanol sclerotherapy after Itrasoundguided fine needle aspiration without anesthesia in the management of simple ovarian cysts. J Minim Invasive Gynecol 2015;22: 475-82.

10. Gupta S, Malhotra N, Sharma D. Oxidative stress and its role in female infertility and assisted reproduction: clinical implications. Int J Fertil Steril. 2009;2(4): 47-164.

11. Tamura H, Takasaki A, Miwa I. Oxidative stress impairs oocyte quality and melatonin protects oocytes from free radical damage and improves fertilization rate. J Pineal Res. 2007;44(3): 280-7.

12. Agarwal A, Gupta S, Abdel-Razek H. Impact of oxidative stress on gametes and embryos in an ART laboratory. Clin Embryol. 2006;9(3): 5-22.

13. Shamsuddin AKM, Guang-Yu Yang. "Inositol \& its Phosphates: Basic Science to Practical Applications", Bentham Science Publishers; 2015. Avail;able from: https:// doi.org/10.2174/97816810800791150101.

14. Buggio L, Somigliana E, Pizzi MN, Dridi D, Roncella $E$ and Vercellini $P$ : 25-hydroxyvitamin $D$ serum levels and endometriosis: Results of a case-control study. Reprod Sci; 2018
15. Hamdan M, Dunselman G, Li TC, Cheong Y. The impact of endometrioma on IVF/ICSI outcomes: a systematic review and meta-analysis. Hum Reprod Update 2015;21: 809-25.

16. Jancar N, Kopitar AN, Ihan A. Effect of apoptosis and reactive oxygen species production in human granulosa cells on oocyte fertilization and blastocyst development. J Assist Reprod Genet. 2007;24(2-3): 91-7.

17. McKinnon B, Bertschi D, Wotzkow C. Glucose transporter expression in eutopic endometrial tissue and ectopic endometriotic lesions. J Mol Endocrinol. 2014;52(2): 169-79.

18. Melo AS, Rosa-e-Silva JC, Rosa-e-Silva AC. Unfavorable lipid profile in women with. Fertility and Sterility. 2010;93(7): 2433-6. DOI: 10.1016/j.fertnstert.2009.08.043.

19. Polak G, Barczyński B, Kwaśniewskn W. Low -density lipoproteins oxidation and endometriosis. Mediators Inflamm. 2013;624540. DOI: 10.1155/2013/624540.

20. Simi G, Genazzani AR, Obino MER. Inositol and in vitro fertilization with embryo transfer. International Journal of Endocrinology. 2017;(5): 1-5. DOI: 10.1155/2017/5469409.

21. SurreyES, Katz-Jaffe M, KondapalliLV, GustofsonRL, Schoolcraft WB. GnRH agonist administration prior to embryo transfer in freeze-all cycles of patients with endometriosis or aberrant endometrial integrin expression. Reprod Biomed Online. 2017;35(2): 145-51. DOI: 10.1016/j. rbmo.2017.05.004

22. The Practice Committee of the American Society for Reproductive Medicine. Endometriosis and infertility: a committee opinion. Fertility and Sterility. 2012;98(3): 591-8. DOI: 10.1016/j.fertnstert.2012.05.031.

23. Halis G, Arici A, Ann NY. Endometriosis and inflammation in infertility. Acad Sci. Annals of the New York Academy of Sciences. 2004;19(8): 2385. DOI: 10.3390/ ijms19082385. 